American Journal of Animal and Veterinary Sciences 2 (4): 72-78, 2007

ISSN 1557-4555

C 2007 Science Publications

\title{
The Determination of Buffering Capacity of Some Ruminant's Feedstuffs and their Cumulative Effects on TMR Ration
}

\author{
A. Moharrery \\ Department of Animal Science, Agricultural College, \\ Shahrekord University, Shahrekord, P.O. Box 115, IRAN
}

\begin{abstract}
Two experiments have been conducted in order to investigate the buffering capacity of some ruminant's feedstuffs and their additivity to calculate ration buffering capacity as a tools for feed formulation. The first experiment was performed with different types (65 samples) of feedstuffs to determine the Buffering Capacity (BC) and Buffer Value Index (BVI). For investigation of cumulative effects of buffering capacity or buffer value index, 6 Total Mixed Rations (TMR) for dairy cow and other six TMR for sheep were formulated using the feedstuffs with known BC or BVI. The calculated and analyzed values were compared using paired t-test. In the second experiment rumen fluid $\mathrm{pH}$ was measured using 5 simple rations on 5 adult sheep and correlation was calculated between rumen fluid $\mathrm{pH}$ and fiber or ash content of the diets. The analyzed BC and BVI for all the TMRs appeared to be lower than the values calculated from these variables, for individual feedstuffs $(p<0.05)$. The analyzed BVI was also two times higher than the calculated BVI for each diet $(\mathrm{p}<0.05)$. In spite of this, the correlation (0.88) between calculated and analyzed values was strong and positive $(\mathrm{p}=0.021)$ for $\mathrm{BC}$ and for BVI (0.64) ( $\mathrm{p}$ and 0.172), respectively. No significant correlation was detected between BC or BVI and non-fiber carbohydrate (NFC) or fiber content of diets $(p>0.05)$. No significant $(p>0.05)$ correlation has been found between ruminal fluid $\mathrm{pH}$ and dietary components.
\end{abstract}

Key words: Buffering capacity, buffering value index, ruminant, feedstuffs

\section{INTRODUCTION}

Buffers in ruminant rations are compounds that neutralize excess acid within the animal's digestive system. The ruminant animal has a complex acid-base regulation system that differs from other animal species. The rumen $\mathrm{pH}$ has been directly related to rumen VFA concentration ${ }^{[7]}$. The prediction of ruminal $\mathrm{pH}$ has been a major concern of ruminant nutritionists for many years and $\mathrm{HCO}_{3}{ }^{-}$is thought to be an important buffer of in the rumen $\mathrm{pH}^{[2]}$ and is most used in most in vitro media for fermentation studies ${ }^{[4]}$. Buffering capacity (BC) refer to the number of moles of $\mathrm{H}^{+}$that must be added to $1 \mathrm{~L}$ of solution to decrease the $\mathrm{pH}$ by 1 unit ${ }^{[11]}$. This value depends on the buffer system and on the $\mathrm{pH}$. Weak acids and bases provide better buffering than strong acids and bases because of the establishment of equilibrium between the acid and the conjugate base.

In this regard, Buffer Value Index (BVI) is related directly to $\mathrm{BC}$ but inversely to $\mathrm{H}^{+}$(acidity). Jasaitis et al. ${ }^{[5]}$ evaluated the $\mathrm{pH}$ and $\mathrm{BC}$ of different feedstuffs. Feedstuffs influence the ruminal acid-base status through their $\mathrm{pH}, \mathrm{BC}$ and stimulation of salivation ${ }^{[8]}$. Tucker et al. ${ }^{[12]}$ reported that BVI could be used to evaluate the $\mathrm{pH}$ and $\mathrm{BC}$ of either the diet or the ruminal fluid. If the total dietary BVI predict the ruminal fluid status, this index could be utilized as tools to predict when supplemental dietary buffers would be beneficial.

The objective of this study was firstly to find $\mathrm{BC}$ and BVI of some ruminant feedstuffs and evaluate the relationships between calculated and analyzed dietary $\mathrm{BC}$ and $\mathrm{BVI}$ of mixed rations and secondly, finding any relation among the total dietary BVI and ruminal fluid $\mathrm{pH}$.

\section{MATERIALS AND METHODS}

First experiment Common ruminant's feeds were divided in seven groups as: forage, silage, straw, protein concentrate, grains, by-product materials and feed supplements. The buffering capacity was defined as the resistance to change in $\mathrm{pH}$ from 7 to 5 . In order to prepare samples for BC determination, individual feedstuffs were dried and ground to pass through 1-mm screen. To avoid VFA loss during drying, BC of silage was determined with a wet sample in an amount equivalent to $0.5 \mathrm{~g}$ of DM. For other feeds, $0.5 \mathrm{~g}$ of dry 
American J. Animal \& Vety. Sci., 2 (4): 72-78, 2007

matter dispensed into a $100-\mathrm{ml}$ beaker and mixed with $30 \mathrm{~mL}$ of distilled, deionized water. The initial $\mathrm{pH}$ of feed was recorded after allowing $2 \mathrm{~min}$ for equilibrium. Buffering capacity was determined by titrating the 30-ml solution under continuous stirring from its initial $\mathrm{pH}$ to $\mathrm{pH}$ of 5 with $1 \mathrm{~N} \mathrm{HCl}$ and by titrating a similar prepared solution of feedstuff from its initial $\mathrm{pH}$ to $\mathrm{pH}$ of 7 with $1 \mathrm{~N} \mathrm{NaOH}$. If the initial $\mathrm{pH}$ was higher than 7 , only the volume of acid required to reduce the $\mathrm{pH}$ from 7 to 5 was recorded. The $\mathrm{BC}$ was converted to milliequivalents per liter as follows:

$\mathrm{BC}=(($ milliliter of $1 \mathrm{~N} \mathrm{HCl})+($ milliliter of $1 \mathrm{~N}$ $\mathrm{NaOH}) \times 10^{3} / 30$. The BVI was calculated according to the formula of Tucker et al. (1992) as follow:

BVI $=\left(\left(\left(\left(\right.\right.\right.\right.$ antilog $\left._{10} \quad(-\mathrm{STPH})\right)-\left(\operatorname{antilog}_{10}\right)$ $\mathrm{SAPH})) /\left(\operatorname{antilog}_{10} \quad(-\mathrm{STPH})\right)+(\mathrm{SABC}-$ $\mathrm{STBC}) / \mathrm{STBC})) \times 10)+100$, where $\mathrm{STPH}=\mathrm{a}$ standard $\mathrm{pH}$ of 6

$\mathrm{SAPH}=$ the feed sample $\mathrm{pH}$

$\mathrm{SABC}=$ the feed sample $\mathrm{BC}$ (milliequivalents per liter)

STBC $=$ a standard BC of 50 meq $\mathrm{L}^{-1}$

Twelve totals mixed rations (TMR), six for dairy cattle and six others for sheep were formulated using the feedstuffs with known BC and BVI. The BVI and $\mathrm{BC}$ calculations for the TMR were determined from individual feedstuffs (assuming additived) and measured for each one of twelve rations separately (Table 1, 2).

Second experiment Five Lory-Bakhtiary male sheep, 12 months old and with live weights from 55 to $58 \mathrm{~kg}$ were used in this experiment. The animals were kept in metabolism boxes. Five total mixed rations (Table 7) were given to animals at maintenance level (1M). The animals were fed twice a day at $0700 \mathrm{~h}$ and $1800 \mathrm{~h}$ and had free access to fresh water. Maintenance requirement of feed for each animal was calculated as:

$$
\text { Feed required }(\mathrm{g} / \text { day })=\mathrm{W}^{0.75} \times 450 / 1000 / \mathrm{ME}
$$

Where $\mathrm{W}$ is the live weight of the animal, 450, the maintenance $\mathrm{ME}$ requirement $\left(\mathrm{kj} / \mathrm{kg} \mathrm{W}^{0.75}\right)^{[1]}$ and $\mathrm{ME}$ is the $\mathrm{ME}(\mathrm{kj} / \mathrm{kg})$ content of the diet.

Experimental period was 21 days and in the last day rumen fluid sample was collected after 21 days adaptation period with help of suction stomach tube and taken directly to the laboratory for measurement of $\mathrm{pH}$ with a glass electrode. Acid detergent fiber (ADF) and non-fiber carbohydrate (NFC) in the feed was determined by a method of Van Soest et al. ${ }^{[13]}$. The
Table 1: Composition of totals mixed rations (TMR) formulated for dairy cattle (DM basis)

\begin{tabular}{lllllll}
\hline \multicolumn{7}{c}{ dairy cattle (DM } \\
& \multicolumn{7}{c}{ Ration $(\%)$} & & & & \\
& ----------- \\
& A & B & C & D & E & F \\
\hline Alfalfa hay & 17 & 20 & 25 & 13.3 & 35.06 & 31.58 \\
Corn silage & 30 & 25 & 20 & 26.5 & 11.69 & 21.05 \\
Barley grain & 3 & 11 & 32 & 20.8 & 21.62 & 21.05 \\
Corn grain & 15.5 & 15.5 & 13.5 & & & \\
Beet pulp & 15 & 1.5 & 2 & & 11.69 & 10.53 \\
Wheat bran & 2 & 3 & 1 & 19 & 14.03 & 10.53 \\
Fish meal & 4 & 0.5 & 0.2 & & & \\
Cotton seed meal & 0.5 & 20 & 2 & 18.5 & 5.84 & 5.26 \\
Soybean meal & 10.5 & 1 & 0.5 & & & \\
Urea & & 0.2 & 1.5 & & & \\
Salt & 0.7 & 0.7 & 0.7 & 0.4 & & \\
Limestone & 0.5 & 0.5 & 0.5 & 1.1 & 0.07 & \\
Dicalcium phosphate & 1.05 & 0.86 & 0.85 & & & \\
Sodium bicarbonate & 0.25 & 0.25 & 0.25 & 0.4 & & \\
pH & 5.70 & 5.74 & 5.84 & 6.32 & 5.69 & 5.38 \\
\hline
\end{tabular}

Table 2: Composition of totals mixed rations (TMR) formulated for sheep (DM basis)

\begin{tabular}{|c|c|c|c|c|c|c|}
\hline & \multicolumn{6}{|c|}{ Ration (\%) } \\
\hline & G & $\mathrm{H}$ & I & $\mathrm{J}$ & $\mathrm{K}$ & $\mathrm{L}$ \\
\hline Alfalfa hay & & & & 16.00 & 27.00 & 21.70 \\
\hline Wheat straw & & & & 11.00 & 17.00 & 3.00 \\
\hline Barley straw & 48.00 & 48.00 & & & & \\
\hline Rice straw & & & 48.00 & & & \\
\hline Barley grain & & & & 32.00 & 20.00 & 60.50 \\
\hline Corn grain & 20.80 & 20.80 & 15.60 & 11.00 & 7.00 & \\
\hline Beet pulp & & & & 10.00 & 11.60 & \\
\hline Wheat bran & 13.52 & 13.52 & 11.44 & 10.00 & 6.00 & 7.90 \\
\hline Plant oil & & & 5.20 & & & \\
\hline Cotton seed meal & 5.20 & 5.20 & 6.24 & 8.00 & 9.40 & 4.80 \\
\hline Soybean meal & 7.28 & 5.20 & 8.32 & & & \\
\hline Urea & & 2.057 & & & & \\
\hline Salt & 1.04 & 1.04 & 1.04 & 0.60 & 0.90 & 0.50 \\
\hline Limestone & 1.04 & 1.04 & 1.04 & 1.00 & 0.50 & 1.04 \\
\hline Dicalcium pho & 2.08 & 2.08 & 2.08 & & & \\
\hline Mineral supplement & 0.52 & 0.52 & 0.52 & 0.20 & 0.30 & 0.10 \\
\hline Vitamin supplement & 0.52 & 0.52 & 0.52 & 0.20 & 0.30 & 0.10 \\
\hline $\mathrm{pH}$ & 7.46 & 6.64 & 6.21 & 7.56 & 6.66 & 8.56 \\
\hline
\end{tabular}

BVI and BC calculations for all rations were determined for whole ration, separately

Correlation was calculated between rumen fluid $\mathrm{pH}$ and fiber or NFC content of the diets.

The paired t-test of SAS ${ }^{[10]}$ was used for comparing calculated or analyzed BC and BVI. The correlation among parameters acids was determined and correlation coefficients were tested using a t-test ${ }^{[10]}$.

\section{RESULTS}

First experiment

Initial pH, BC and BVI: Initial pH of ingredients, analyzed BC and BVI for different classes of feedstuffs are presented in Table 3 . Initial $\mathrm{pH}$ varied from around neutral value (6.98 for triticale) to an acidic one (3.61 
for pomegranate by-product silage). Three feedstuffs had very low $\mathrm{pH}$ values around 4 (corn silage, sugar beet pulp silage, pomegranate by-product silage).

The buffering capacity of barley straw was about 3.7 times higher than for wheat straw, but not much difference could be seen between rice straw and wheat straw (Table 3). The fermented feedstuffs have negative BVI and the most negative BVI was found for pomegranate by-product silage (Table 3 ). High negative BVI was also found for the dicalcium phosphate (DCP), which is produced by reaction of phosphoric acid on phosphate rock. Generally, BC in forage and protein concentrate are 5.6 and 4.1 times higher than $\mathrm{BC}$ in grains, respectively (Table 3 ).

It can be seen that, two feed samples with similar BVI potentially could have very different $\mathrm{pH}$ or different $\mathrm{BC}$, however, to preserve this similarity in $\mathrm{BVI}$, a reduction in one variable $(\mathrm{pH}$ or $\mathrm{BC})$ must be offset by an increase in the other. For example the BVI of barley straw is 98.94 and the BVI for wheat grain is more or less same (98.34), but the BC in barley straw is 8.35 times of wheat grain (Table 3). Within protein concentrate BC varied between 0.24 (urea) and 6.85 (fish meal) and for grain the $\mathrm{BC}$ varied between 0.71 (corn) and 1.22 (sorghum). Generally, BC was weak negative but not significantly $(\mathrm{p}=0.135)$ correlated with initial $\mathrm{pH}(\mathrm{r}=-0.22, \mathrm{n}=46)$. In this regard, BVI was positively correlated with initial $\mathrm{pH}(\mathrm{r}=0.68$, $\mathrm{p}<0.0001)$.

Reaction of the fermented feedstuffs in relation to the sodium hydroxide addition

The second part of determination of buffering capacity was titration of a $30-\mathrm{ml}$ aliquot from its original $\mathrm{pH}$ to $\mathrm{pH} 7$ with $1 \mathrm{~N} \mathrm{NaOH}$. In relation to the $\mathrm{BC}$ of the feedstuffs the pattern of the neutralizing curve was changed according the chemical composition. In this regard, beet pulp silage with or without wheat straw (plus molasses in some case) showed different pattern of neutralizing (Fig. 1). Based of data in Fig. 1 the consumption of $1 \mathrm{~N} \mathrm{NaOH}$ solution was reduced by increasing the wheat straw percentage. On the other hand, addition of molasses to the sugar beet pulp silage prior to the ensiling increased the amount of $1 \mathrm{~N} \mathrm{NaOH}$ solution needed for neutralizing of sample. For each percent of wheat straw addition to the sugar beet pulp silage, $10.625 \mu \mathrm{L}$ less of $1 \mathrm{~N} \mathrm{NaOH}$ solution was needed for neutralizing the samples. In this regard, the initial $\mathrm{pH}$ value for increasing of each percent of wheat straw was increased by 0.045 .

Additionally, the Volatile Fatty Acids (VFA), which were produced during ensiling of corn affects the consumption of $1 \mathrm{~N} \mathrm{NaOH}$ solution for neutralizing samples. Figure 2 shows different alkaline solution consumption for fresh and oven dry corn silages. The fresh corn silage needed more $1 \mathrm{~N} \mathrm{NaOH}$ solution to neutralize to level of $7 \mathrm{pH}$. Part of this was related to the presence of VFA in the fresh corn silage compared to dry corn silage. Using regression equation for both curves in the Fig. 2, it is possible to calculate amount of $1 \mathrm{~N} \mathrm{NaOH}$ used mainly to neutralize the VFA content in the fresh corn silage. In these samples, by subtracting dry equation from fresh equation and solving reminder for $x$ the value of 138.1 is found. This value means that for neutralizing the VFA content in each gram of fresh corn silage needed $276.2 \mu \mathrm{L}$.

Figure 3 shows the $\mathrm{pH}$ response to $1 \mathrm{~N} \mathrm{NaOH}$ titration for neutralization of two types of silage. The pattern of neutralizing corn silage is curvilinear but, the pattern of neutralizing pomegranate silage (fresh) is linear. The higher consumption of $1 \mathrm{~N} \mathrm{NaOH}$ solution in the pomegranate silage is probably due to higher acid production during ensiling.

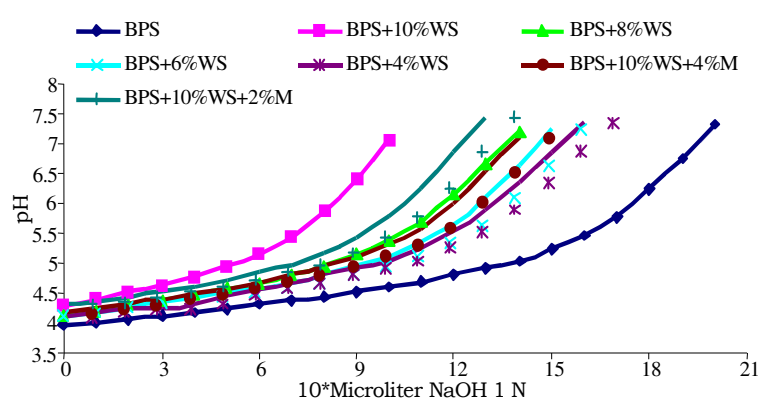

Fig. 1: Titration curve of sugar beet silage (BPS) and mixed BPS with Wheat Straw (WS) and/or molasses (M)

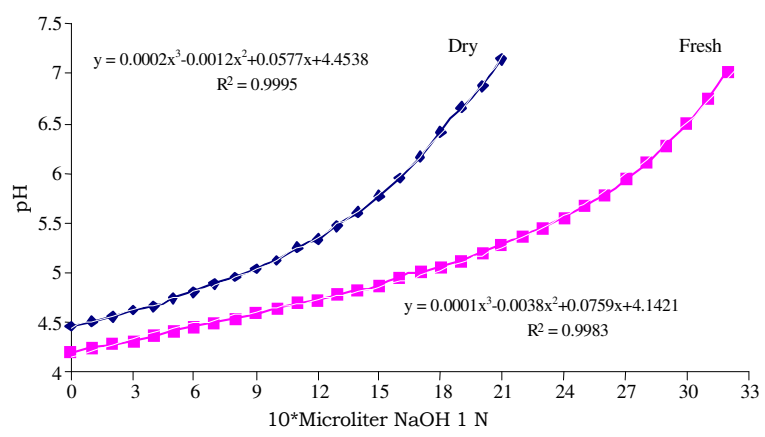

Fig. 2: The difference in $\mathrm{pH}$ between fresh and oven dried corn silage in titration with sodium hydroxide 
American J. Animal \& Vety. Sci., 2 (4): 72-78, 2007

Table 3: Buffering capacity (BC, meq $\mathrm{L}^{-1}$ ) and buffer value index (BVI) of selected feedstuffs

\begin{tabular}{|c|c|c|c|c|}
\hline & Scientific name & Initial $\mathrm{pH}$ & $\mathrm{BC}$ & BVI \\
\hline \multicolumn{5}{|l|}{ Forage } \\
\hline Alfalefa & Medicago sativa & 6.27 & 5.32 & 95.693 \\
\hline Sainfoin & Onobrychis vicifolia & 6.38 & 4.44 & 96.672 \\
\hline Salad crop & Poterium sanguisorba & 6.17 & 6.24 & 94.410 \\
\hline Perennial grass & Poacea & 6.44 & 4.00 & 97.169 \\
\hline Clover hay & Trifolium repens & 6.30 & 5.21 & 95.971 \\
\hline Fresh clover & Trifolium repens & 6.37 & 4.13 & 96.510 \\
\hline \multicolumn{5}{|l|}{ Straw } \\
\hline Rice straw & Oryza sativa & 5.94 & 1.10 & 88.739 \\
\hline Wheat straw & Triticum aestivum & 5.82 & 1.78 & 85.220 \\
\hline Barley straw & Hordeum vulgare & 6.62 & 6.68 & 98.937 \\
\hline \multicolumn{5}{|l|}{ Silage } \\
\hline Corn silage (fresh) & Zea mays indentata & 4.19 & 10.18 & -543.618 \\
\hline Corn silage (dry) & & 4.46 & 6.83 & -245.372 \\
\hline Sugar beet pulp & & 3.97 & 6.48 & -970.223 \\
\hline Sugar beet pulp $+10 \%$ wheat straw (silage) & & 4.29 & 3.28 & -412.205 \\
\hline Sugar beet pulp+8\%wheat straw (silage) & & 4.14 & 4.54 & -623.528 \\
\hline Sugar beet pulp $+6 \%$ wheat straw (silage) & & 4.12 & 4.88 & -657.602 \\
\hline Sugar beet pulp $+4 \%$ wheat straw (silage) & & 4.11 & 5.09 & -675.229 \\
\hline Sugar beet pulp $+10 \%$ wheat straw $+2 \%$ Molasses (silage) & & 4.18 & 4.61 & -559.771 \\
\hline Sugar beet pulp $+10 \%$ wheat straw $+4 \%$ Molasses (silage) & & 4.32 & 4.09 & -377.813 \\
\hline Pomegranate by-product (silage) & Punica granatum & 3.61 & 7.16 & -2353.277 \\
\hline \multicolumn{5}{|l|}{ Treated straw } \\
\hline Straw $+3 \%$ Urea & Triticum aestivum & 5.58 & 1.61 & 73.715 \\
\hline Straw $+6 \%$ Urea & & 5.88 & 1.44 & 86.954 \\
\hline Straw+9\% Urea & & 5.84 & 1.51 & 85.680 \\
\hline Straw $+6 \%$ Urea $+10 \%$ Molasses & & 5.56 & 2.08 & 72.874 \\
\hline Straw $+3 \% \mathrm{NaOH}$ & & 9.64 & 8.10 & 101.618 \\
\hline \multicolumn{5}{|l|}{ Protein concentrate } \\
\hline Cotton seed meal & Sossypium spp. & 6.44 & 2.24 & 96.775 \\
\hline Soybean meal & Glycine $\max$ & 6.81 & 4.74 & 99.399 \\
\hline Fish meal & Brevoortia tyrannus & 5.86 & 6.85 & 87.406 \\
\hline Blood meal & & 5.43 & 3.37 & 63.090 \\
\hline Meat meal & & 6.34 & 4.13 & 96.255 \\
\hline Urea & & 7.80 & 0.24 & 99.982 \\
\hline \multicolumn{5}{|l|}{ Grain } \\
\hline Corn grain & Zea mays indentata & 6.72 & 0.71 & 98.215 \\
\hline Barley grain & Hordeum vulgare & 6.01 & 0.97 & 90.421 \\
\hline Hulless barley & Hordeum vulgare & 6.04 & 0.73 & 91.025 \\
\hline Wheat (Alvand var.) & Triticum aestivum & 6.74 & 0.80 & 98.341 \\
\hline Wheat (Omid var.) & Triticum aestivum & 6.67 & 0.81 & 97.998 \\
\hline Triticale & Triticosecale & 6.98 & 0.85 & 99.123 \\
\hline Sorghum & Sorghum bicolor & 6.68 & 1.22 & 98.129 \\
\hline \multicolumn{5}{|l|}{ By-product } \\
\hline Wheat bran & Triticum aestivum & 6.87 & 2.09 & 99.054 \\
\hline Bagasse & Saccharum officinarum & 6.47 & 1.54 & 96.880 \\
\hline Sugar beet aerial parts & Beta vulgaris altissima & 5.86 & 4.73 & 86.983 \\
\hline Molasses & & 4.78 & 2.56 & -65.447 \\
\hline Sugar beet pulp plated & & 5.01 & 1.77 & 2.630 \\
\hline Sugar beet pulp & & 5.42 & 1.03 & 62.188 \\
\hline Rice hull & Oryza sativa & 6.25 & 0.28 & 94.433 \\
\hline Tomato by-product & Lycopersicon esculentum & 4.73 & 3.52 & -85.505 \\
\hline Broiler excreta & Gallus domesticus & 6.33 & 10.00 & 97.268 \\
\hline \multicolumn{5}{|l|}{ Supplement } \\
\hline Salt & & 6.25 & 0.19 & 94.349 \\
\hline Magnesium oxide & & 11.21 & 3.40 & 101.124 \\
\hline Limestone & & 11.74 & 317.00 & 163.400 \\
\hline Mineral supplement & & 5.42 & 31.18 & 67.777 \\
\hline Vitamin supplement & & 7.43 & 25.67 & 104.762 \\
\hline Dicalcium phosphate & & 3.76 & 58.67 & -1626.067 \\
\hline Sodium bicarbonate & & 8.13 & 188.83 & 136.493 \\
\hline
\end{tabular}




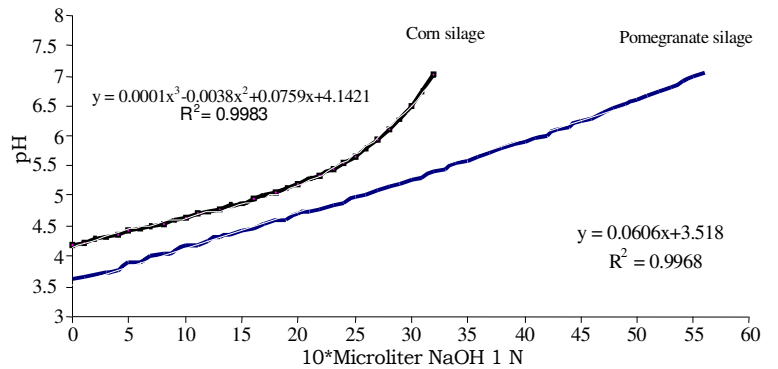

Fig. 3: The difference between fresh corn silage and fresh pomegranate pulp silage in reaction to sodium hydroxide

Evaluation of the cumulative effect for BC and BVI: The concept of mixing feeds of known buffering potential to create a diet with predictable BC assumes that the range of feed $\mathrm{BC}$, both within and among feed types, is large enough to allow formulation of diets that vary in $\mathrm{BC}$ yet are similar in nutrient content. If this range did not exist, it would not be possible to make substitution of one feed for another. Result of the first experiment showed that analyzed dietary BVI and BC were markedly higher than BVI and BC values calculated from individual dietary components (Table 4). The titration of all 12 TMRs (cattle and sheep rations) indicated that the overall $\mathrm{BC}$ of feed mixtures were not similar to the one predicted by summing the weighted BC values for the individual feeds (weighed based on percentage of the feed in the diet). This means that the BVI and BC for individual dietary ingredient did not cumulative effect on TMR. However, the correlation between calculated BC and analyzed BC is high $(\mathrm{r}=0.89)$ and significant $(\mathrm{p}<0.05$, Table 5), but the coefficient of correlation between calculated BVI and analyzed BVI could not showed stronger relationship as seen for BC (Table 5). The regression equation for prediction of $\mathrm{BC}$ and $\mathrm{BVI}$ is shown in Table 6 . For cattle diets around $85 \%$ of the variance of analyzed $\mathrm{BC}$ was explained by the calculated BC but, only $77 \%$ in BC for sheep diets. Nevertheless, low $\mathrm{R}^{2}$ and non significant probability ( $>0.05)$ indicated that this simple model was insufficient to estimate accurately BVI in both types of mixed rations.

Second experiment: Diet compositions and values for dietary BVI, ADF, CF and RDP which were fed to the five sheep are presented in Table 7 . Rumen $\mathrm{pH}$ ranged from 6.35 to 6.66 and declined in response to increased percentage of NFC in the rations but was not influenced by RDP\%. Dietary treatments affected the rumen $\mathrm{pH}$. Increasing the barley grain up to $20 \%$ (diet D v diet A) did not affect rumen $\mathrm{pH}$ significantly but, adding 10 percent more barley to the diet (diet C) significantly decreased rumen $\mathrm{pH}$. In this regard, it seems that dietary ADF\% and BVI had a better relationship with ruminal fluid $\mathrm{pH}$ compared to other components mentioned earlier (Table 8). A high dietary ADF or low NFC concentration increased ruminal fluid $\mathrm{pH}$. However, no significant ( $\mathrm{p}>0.05$ ) correlation has been found between ruminal fluid $\mathrm{pH}$ and dietary components (Table 8).

Table 4: Buffering capacity (BC, meq $\mathrm{L}^{-1}$ ) and buffer value index (BVI) of different type of sheep and dairy cow diets

\begin{tabular}{llllll}
\hline Diet & First pH & $\begin{array}{l}\text { BC } \\
\text { (calculated) }\end{array}$ & $\begin{array}{l}\text { BC } \\
\text { (analyzed) }\end{array}$ & $\begin{array}{l}\text { BVI } \\
\text { (calculated) }\end{array}$ & $\begin{array}{l}\text { BVI } \\
\text { (analyzed) }\end{array}$ \\
\hline Sheep & & & & & \\
A & 7.46 & 8.912 & 6.556 & 63.335 & 100.964 \\
B & 6.64 & 8.818 & 5.831 & 63.325 & 98.849 \\
C & 6.21 & 6.116 & 2.727 & 53.312 & 94.380 \\
D & 7.56 & 5.206 & 3.222 & 84.879 & 100.366 \\
E & 6.66 & 4.229 & 3.427 & 82.813 & 98.572 \\
F & 8.56 & 6.560 & 4.700 & 93.429 & 100.913 \\
Cattle & & & & & \\
G & 5.70 & 6.729 & 3.811 & -37.870 & 80.579 \\
H & 5.74 & 6.044 & 3.190 & -5.203 & 82.441 \\
I & 5.84 & 5.688 & 3.425 & 10.190 & 86.063 \\
J & 6.32 & 7.748 & 4.841 & 5.956 & 96.126 \\
K & 5.69 & 3.724 & 2.798 & 44.386 & 80.142 \\
L & 5.38 & 3.843 & 2.409 & 13.400 & 58.795 \\
Mean & & 6.130 & 3.910 & 39.300 & 89.800 \\
SEM & & 0.506 & 0.375 & 11.95 & 3.680 \\
p value & & 0.0001 & & 0.0004 & \\
\hline
\end{tabular}

Table 5: Coefficient of correlation between calculated and analyzed buffering capacity (BC, meq $\mathrm{L}^{-1}$ ) and buffer value index (BVI)

\begin{tabular}{|c|c|c|c|}
\hline & BC (analyzed) & BVI (analyzed) & References \\
\hline $\begin{array}{l}\mathrm{BC} \\
\text { (calculated) }\end{array}$ & $\begin{array}{l}0.8892^{\mathrm{a}} \\
0.0001^{\mathrm{b}}\end{array}$ & & Present study \\
\hline $\begin{array}{l}\text { BVI } \\
\text { (calculated) }\end{array}$ & & $\begin{array}{l}0.6385 \\
0.0254\end{array}$ & Present study \\
\hline $\begin{array}{l}\mathrm{BC} \\
\text { (calculated) }\end{array}$ & $\begin{array}{l}0.9584 \\
0.0416\end{array}$ & & Le Ruyet et al. (1992) \\
\hline $\begin{array}{l}\text { BVI } \\
\text { (calculated) }\end{array}$ & & $\begin{array}{l}0.8160 \\
0.1840\end{array}$ & Le Ruyet et al. (1992) \\
\hline
\end{tabular}

a: coefficient of correlation, b: probability level

Table 6: Regression equation for prediction of $\mathrm{BC}\left(\mathrm{meq} \mathrm{L}^{-1}\right)$ and BVI

\begin{tabular}{|c|c|c|c|c|}
\hline Diets & Equation & $\mathrm{R}^{2}$ & \multicolumn{2}{|c|}{ p-value References } \\
\hline Cattle & 0.5995 (calculated BC) & 0.83 & 0.0066 & Present study \\
\hline Cattle & 80.9-0.0490 (calculated BVI) & 0.01 & 0.8397 & Present study \\
\hline Sheep & 0.6674 (calculated BC) & 0.77 & 0.0209 & Present study \\
\hline Sheep & $91.6+0.1$ & 0.41 & 0.1721 & Present study \\
\hline Cattle & 0.7741 & 0.81 & 0.0416 & uyet et al. \\
\hline Cattle & $67.0+0.268$ (calculated BVI) & 0.67 & 0.1840 & $\begin{array}{l}\text { Le Ruyet et al. } \\
\text { (1992) }\end{array}$ \\
\hline $\begin{array}{l}\text { Total } \\
\text { diets }\end{array}$ & 0.639 (calculated BC) & 0.79 & 0.0001 & Present study \\
\hline $\begin{array}{l}\text { Total } \\
\text { diets }\end{array}$ & $82.1+0.197$ (calculated BVI) & 0.41 & 0.0254 & Present study \\
\hline
\end{tabular}

diets 
American J. Animal \& Vety. Sci., 2 (4): 72-78, 2007

Table 7: Ingredient and composition of sheep diets (DM basis)

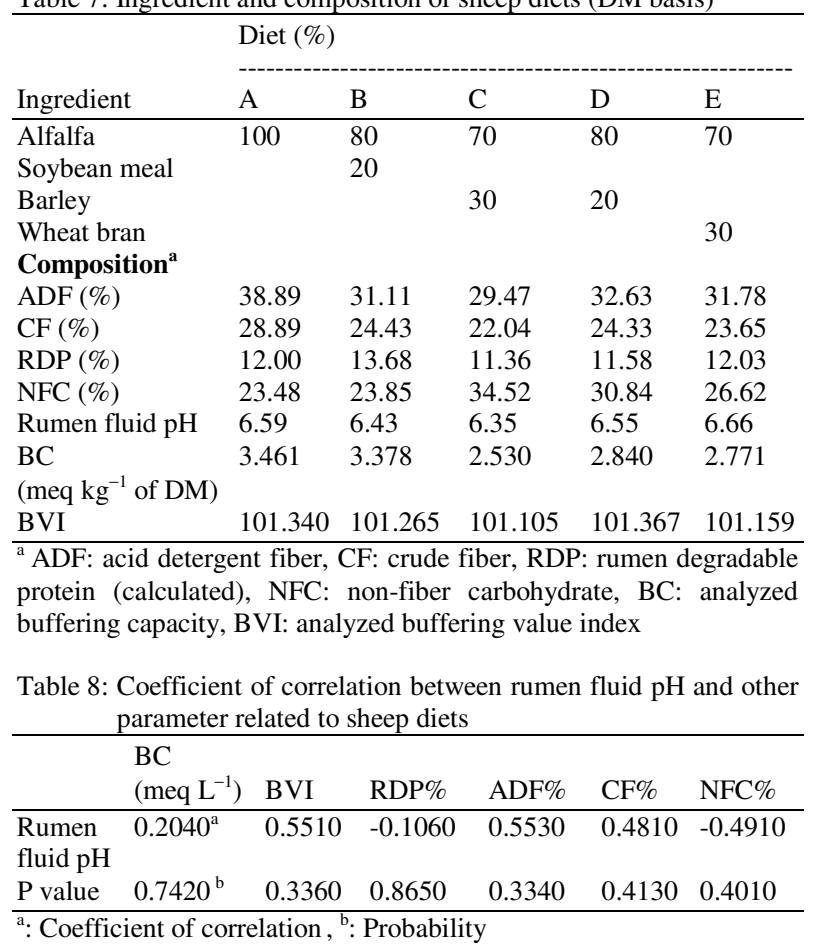

\section{DISCUSSION}

The ruminants have three primary means of buffering either acid ingested or acid produced by rumen microorganisms. These include: 1) buffers naturally occurring in saliva, 2) buffering capacity of ingested feed and 3) added dietary buffers. It is important to consider the need for dietary buffer only as a method of overcoming shortfalls in saliva and natural feed buffering constituents.

Because rumen $\mathrm{pH}$ seldom exceeds the range of 5 to 7 in dairy cows fed diets containing 40 to $90 \%$ forage, buffering capacities measured within that range would be more appropriate than the ranges of 4 to $9^{[5]}$ or 4 to $6^{[9]}$. This is logical in that buffering capacities measured over range of 4 to 9 may not be related at all to buffering capacity in the physiological $\mathrm{pH}$ range in the rumen of 5.5 to 7.0 .

The ratio between the amounts of sample and distilled water was higher than that used by Jasaitis et al. ${ }^{[5]}$, but of the same magnitude than that of Le Ruyet et al. ${ }^{[8]}$. Nevertheless, the initial $\mathrm{pH}$ values were close to those obtained by Jasaitis et al. ${ }^{[5]}$ on feedstuffs. In agreement with the result of present study, the work of Jasaitis et al. ${ }^{[5]}$ showed that cereal grains had relatively low buffering capacities but hays and protein sources had three to four fold higher total buffering capacities in the $\mathrm{pH}$ range of 4 to 9 . Dry feeds near $\mathrm{pH} 6$ such as forages would allow for substantial buffering in high grain diets regardless of their physical effects on salivation.

Fermented feedstuffs had quit low initial $\mathrm{pH}$ values as already found by Playne and McDonald, ${ }^{[9]}$ and by Le Ruyet et al. ${ }^{[8]}$ and by Giger-Riverdin et al. ${ }^{[3]}$. The values obtained (mean value $=4.1$ ) were acidic. These low $\mathrm{pHs}$ have to be related to the fact that such a $\mathrm{pH}$ is necessary to conserve these feedstuffs. In the present study a cubic model was used to describe the titration curves and the fit was quite good (Fig. 2 and 3). Cubic model seemed better than the exponential one proposed by Giger-Riverdin et al. ${ }^{[3]}$. This result is in agreement to Wohlt et al. ${ }^{[14]}$ who has reported that the titration curve for acidic feedstuffs is better explained by cubic models.

The mixing with wheat straw before ensiling of sugar beet pulp to increase dry matter content of the silage and reduce run off soluble material due to compression of silage resulted acid formation during ensiling period. This reduction was not linear but a mean value of about $0.045 \mathrm{pH}$ unit for each added percent of wheat straw. On the other hand, the titration curve for pomegranate by-product silage was linear. The reason for this curve type was partly due to the presence of some inorganic acid in this by-product but, needs more research about it. In respect to the measurement of alkaline $(1 \mathrm{~N} \mathrm{NaOH})$ consumption for neutralizing corn silage in a fresh and dry form it is possible to predict the mole of volatile acid, which disappeared during oven drying of corn silage. In addition to measuring alkaline consumption it is possible to subtract dry silage curve from fresh silage curve and solving the reminder for $\mathrm{X}$. In the present study $\mathrm{X}$ was 276.2 micro liters $1 \mathrm{~N} \mathrm{NaOH}$ for each gram of corn silage (dry matter basis). It presented the advantage of allowing the calculation of the volatile acid component and it can be used for practical feeding where the potential acid loads of the feeds in the rumen due to their consumption.

The pretreatment of feedstuffs with urea could not modify their properties since the alkaline buffering capacities were not changed compared to untreated wheat straw. In this regard the $\mathrm{NaOH}$ treated wheat straw showed higher BC because of a high initial $\mathrm{pH}$.

The result of the present study could not show a cumulative effect for $\mathrm{BC}$ and $\mathrm{BVI}$ but, using the equation suggested (Table 6) it is possible to predict $\mathrm{BC}$ for diet with fermented ingredient (cattle rations) or without fermented materials (sheep rations). These results are in contrasts with Jasaitis et al. ${ }^{[5]}$, who were able to predict the $\mathrm{BC}$ of a TMR from the individual feed $\mathrm{BC}$, but, in their analysis, the silage was dried 
before it was mixed with other ingredients, a broader $\mathrm{pH}$ range was used to calculate $\mathrm{BC}$ and the complete dietary $\mathrm{BC}$ was determined immediately after mixing. In agreement with these results, Le Ruyet et al. ${ }^{[8]}$ found similar relationships between calculated and analyzed dietary BVI. However, their samples were frozen for 4 month's before analysis. The analyses in present study were conducted after the samples were taken.

Variation in experimental procedures and method of collection rumen fluid for $\mathrm{pH}$ measurement make it difficult to compare the results of this study with other reports of rumen $\mathrm{pH}$ and feed main components. Kaufmann ${ }^{[6]}$, using lactating dairy cows, predicted average rumen $\mathrm{pH}$ as a linear function of dietary crude fiber where a 1 percentage unit decline in dietary crude fiber resulted in a $0.066 \mathrm{pH}$ unit decline in rumen $\mathrm{pH}$ $\left(\mathrm{R}^{2}=0.81, \mathrm{p}<0.01\right)$. In the present study 1 percentage unit decline in dietary $\mathrm{CP}, \mathrm{ADF}, \mathrm{NFC}$ and $\mathrm{BC}$ (meq $\mathrm{L}^{-1}$ ) changed rumen $\mathrm{pH}$ with $-0.024,-0.020,0.013$ and -0.063 , respectively but, because the $\mathrm{R}^{2}$ were low $(0.31)$ and not significant $(p>0.05)$ result was not reported. Erdman ${ }^{[2]}$, in his literature review paper's reported a linear relationship between rumen $\mathrm{pH}$ and dietary ADF content where: rumen $\mathrm{pH}=5.34+0.056$ ADF $\left(R^{2}=0.30, p<0.005\right)$. Considering the relationship between ADF and the predicted change in $\mathrm{pH}$ using this equation is higher than whatever find in present study. Additionally, respect to the $\mathrm{R}^{2}(0.30)$ in the above equation, this can be resulted that about $30 \%$ of change in rumen $\mathrm{pH}$ is related to the change in $\mathrm{ADF}$ percentage in the ration.

\section{CONCLUSIONS}

In summary, increases in feed efficiency in ruminants are associated with improvements in fiber digestion. A volume of literature is available, which suggest that better digestion of fiber needs a stable environment of the rumen. A challenge for future research will be the precise determination of buffer conditions in the rumen and to meet deficiencies in buffer capacity due to change in dietary acid consumption and rumen VFA production through change the feed ingredients or buffer supplementation only when dictated.

The present study showed that the BC and BVI of the twelve TMR's differed from those predicted by summing the values for the individual feedstuffs. All analyzed BVI and BC were higher than calculated values. No significant correlation has been found between ruminal $\mathrm{pH}$ and dietary RDP or fiber.

\section{REFERENCES}

1. Chen, X.B., F.D.DeB. Hovell, E.R. Ørskov and D.S. Brown, 1990. Excretion of purine derivatives by ruminants: effects of exogenous nucleic acid supply on purine derivative excretion by sheep. British Journal of Nutrition., 63: 131-142.

2. Erdman, R.A., 1988. Dietary buffering requirements of the lactating dairy cow: a review. Journal of Dairy Science, 71: 3246-3266.

3. Giger-Reverdin, S., C. Duvaux-Ponter, D. Sauvant, O. Martin, I.N. Prado and R. Muller, 2001. Intrinsic buffering capacity of feedstuffs. Animal Feed Science and Technology, 96: 83-102.

4. Goering, H.K. and P.J. Van Soest, 1970. Forage fiber analyses (apparatus, reagents, procedures and some applications). Agric. Handbook No. 179. ARS, USDA, Washington, DC.

5. Jasaitis, D.K., J.E. Wohlt and J.l. Evans, 1987. Influence of fed ion content on buffering capacity of ruminant feedstuffs in vitro. Journal of Dairy Science, 70: 1391-1403.

6. Kaufmann, W., 1976. Influence of the composition of the ration and the feeding frequency on $\mathrm{pH}$ regulation in the rumen and on feed intake in ruminants. Livestock Production of Science., 3: 103-114.

7. Kohn, R.A. and T.F. Dunlap, 1998. Calculation of the buffering capacity of bicarbonate in the rumen and in vitro. Journal of Animal Science, 76: 17021709.

8. Le Ruyet. P., W.B. Tucker, J.F. Hogue, M. Aslam and M. Lema, 1992. Influence of dietary fiber and buffer value index on the ruminal milieu of lactating dairy cows. Journal of Dairy Science, 75: 2394-2408.

9. Playne, M.J. and P. McDonald, 1966. The buffering constituents of herbage and of silage. Journal of Science and Food Agriculture, 17: 264268.

10. SAS User's Guide: Statistics, Version 6.03, 4th Edn. 1988. SAS Inst., Inc., Cary, NC.

11. Segel, I. H., 1976. Biochemical Calculation. 2nd Edn. John Wiley and Sons, New York.

12. Tucker, W.B., J.F. Hogue, M. Aslam, M. Lema, M. Martin, F.N. Owens, I.S. Shin, P. Le Ruyet and G.D. Adams. 1992. A buffer value index to evaluate effects of buffers on ruminal milieu in cows fed high or low concentrate, silage, or hay diets. Journal of Dairy Science., 75: 811-819.

13. Van Soest, P.J., J.B. Robertson and B.A. Lewis, 1991. Methods for dietary fiber, neutral detergent fiber and non-starch polysaccharides in relation to animal nutrition. Journal of Dairy Science, 74: 3583-3597.

14. Wohlt, J.E., D.K. Jasaitis and J.L. Evans, 1987. Use of acid and base titrations to evaluate the buffering capacity of ruminant feedstuffs in vitro. Journal of Dairy Science, 70: 1465-1470. 